\title{
Indonesian Customary Court Concept in the Future
}

\author{
Lilik Mulyadi ${ }^{1} \&$ Ronald Hasudungan Sianturi ${ }^{1}$ \\ ${ }^{1}$ Faculty of Law, Prima Indonesia University, Indonesia \\ Correspondence: Lilik Mulyadi, Faculty of Law, Prima Indonesia University, Jalan Sekip Simpang Sikambing, \\ Medan, North Sumatera, Indonesia. Tel: 82-61-457-8890. E-mail: lilik_unpri@yahoo.com
}

Received: August 16, 2014 Accepted: October 9, 2014 Online Published: April 30, 2015

doi:10.5539/ass.v11n12p1 URL: http://dx.doi.org/10.5539/ass.v11n12p1

\begin{abstract}
This paper initiated the concept of indigenous Indonesian judicial ideal future, oriented to three models of customary courts: first, indigenous justice is independent; second, justice custom in general court; and third, the general court justice for indigenous case with accommodating indigenous values. The selection of the three alternative models in indigenous justice initiated the concept of the ideal future is a choice of how the political dynamics of the existence of the law for justice indigenous ways of looking at one side with the formal law on the other. Clearly, if the customary court will be chosen level with formal law (national law) that is independent; is part of the formal law (national law) entered the room so that the general court, or custom values so as to be accommodated in the national law higher than the customary law as dynamic as it is today.
\end{abstract}

Keywords: customary court, Indonesian juridical, national law

\section{Introduction}

Examined from the perspective of legislation in Indonesia today, customary legal terminology is known as the "law of life in society," "living law," "legal values and sense of justice that live in the community," "the unwritten law,"'customary law,"'native Indonesian law," and so forth. In addition, customary law and its indigenous communities have a strong correlation, integral and inseparable even commonly expressed in some proverbs. For example, suppose the Acehnese people known by the phrase " matee anek mepat custom meshes matee Tamita phat " is defined when a child dies tomb, can still be seen; however, if the custom is removed/dead, it will be difficult to find. Other expressions, such as " murip i kanung Edet, mate i kanung earth," which means that it must follow the same rules with the customary necessity when the dead shall go into the belly of the earth.

Existence of customary law other than the enactment of national legal instruments known in the instrument set also as international. The provisions of Article 15 paragraph (2), the International Covenant on Civil and Political Rights (ICCPR) states that "Nothing in this article shall prejudice the trial and punishment of any person for any act or omission; at the time when it was committed, was criminal According to the general principles of law-recognized companies by the community of nations." Then, the recommendation of the Congress of the United Nations (UN) on "The Prevention of Crime and the Treatment of Offenders" stated that the criminal justice system have existed in some countries (especially those from/imported from a foreign law during the colonial period); the general are "obsolete and unjust" (already outdated and unfair) and "outmoded and unreal" (already out of date and not in accordance with reality). The reason is because the legal systems in some countries are not rooted in cultural values, and there is even a "discrepancy" with the aspirations of the people, and the system is not responsive to the social needs of the present. These conditions by the UN Congress is expressed as a factor contributing to the occurrence of crime.

The scope and dimension of customary law have very broad context; the instrument is set in law, both national and international instruments. In addition, the studied substance of customary law dimension can be divided into the customary civil law, customary constitutional law, criminal law customary (delichtentrecht) and so forth. Customary criminal law terminology, customs offenses, violations of customary law, or common law criminal forerunner to actually derived from customary law. When examined from the perspective of the source, the criminal law/civil customary has written and unwritten sources. Clearly, it can be a source of unwritten customs that arise, followed and adhered to continuously and down for generations by the indigenous peoples concerned. For example, written sources can be seen in the Book Ciwasasana or Purwadhigama during King Dharmawangsa of the 10th century, the Book of Gajah Mada, Simbur Book Light in Palembang, Book Kuntara King Niti in 
Lampung, Book Lontara "ade" in South Sulawesi, Adi Book of Religion, Book Manawa Dharma Sastra, Awig-Awig in Bali, and all the regulations as written on a manuscript, leather, or other materials.

\section{Discussion}

\subsection{Customary Law between "There" and "No"}

Over time, the change is highly complex and dynamic; making of regulatory legislation as partial legislative policy turns out to be an existence of criminal law/criminal justice, and their indigenous customs can be said to be between "no" and "no." There are six arguments put forward in this context.

First, it examined the formal dimension of the principle of legality and the principle of legality material. Basically, the principle of legality with the terminology commonly called "principle of legality," "legaliteitbeginsel," "non-retroactivity," "de lalegalite," or "ex post facto laws." Provisions of the legality principle in Article 1 paragraph (1) of the Criminal Code determines: "Nothing can be convicted of an event other than the power of the criminal law provisions that preceded it. "When paired, formal and material legality principle should be stipulated in legislation and implemented integrally. On the basis of the principle of legality of an action, a convicted law existed before it was committed. Then, the legality principle that the basic material is liable should an act is legal to live in a society is not a written law or customary law.

Barda Nawawi Arief mentions the existence of formal formulation of the principle of legality in Article 1 of the Criminal Code, common law, or the law of life in the community did not have a place as a source of positive law. In other words, the existence of Article 1 of the Criminal Code is often "put to sleep or turned off." During colonial times, the criminal law is not written lull; it still may be because it is in accordance with the Dutch law policy at the time. However, the other will be felt when the policy was also continued after independence. With Section 1 of the Criminal Code, the unwritten law/legal life was never fully excavated and revealed the surface, especially in the practice of criminal justice as well as in academic studies in college. Furthermore, means never develop properly "jurisprudential tradition" or "traditional academic/scholarly" about the criminal law is not written it. If it does exist, it does only in a very limited space and" is not complete."

Basic conclusion from what is described in the above-mentioned principle of legality as the provisions of Article 1 of the Criminal Code, it is one of the fundamental principles that must be maintained but should use it wisely and carefully because if less wise and less careful, it can be "boomerang." It is tragic and disheartening when the pretext of Article 1 of the Criminal Code, the values of the existing law and living in the community, cannot be channelled properly or even rejected altogether. It says that the tragic and heart-rending as mean values of customary law/laws that live in the community have been killed/turned off by his own people through weapons/bullet/knife obtained from the former colonial power (i.e., through Section 1 of the Criminal Code/WvS).

Second, examined from the perspective of Act No. 1 of 1951, which darts Customary Court began its existence is not recognized and eliminated that continues after Basic Law on Judicial Power codification (Act No. 14 of 1970), which is then converted by Law No. 35 of 1999, in conjunction with Law No. 4 of 2004, Act No. 48 of 2009) no longer recognized the existence of customary courts. The provisions of Article 1 (2) $1 \mathrm{drt}$ Act of 1951stated that, "At the time, will gradually abolished determined by the Minister of Justice....all Customary Courts except if the religious courts of justice according to law that life is a separate part of the Indigenous justice."Then, the article is an authentic explanation stating the basis for consideration of elimination of indigenous customary justice because justice does not qualify as a court equipment as requested by the Provisional Constitution and undesirable people. However, in the abolition of customary justice in the above context, the fact does not eliminate the type of justice that is customary in other forms of village justice. Aspects and dimensions of the starting point as the provisions of Article 1 (3) 1 drt Act of 1951, which asserted that "The provisions mentioned in subsection (1) is not the slightest power to reduce the rights had been given to the judges of the peace in villages referred to in article 3a Rechterlijke Organisatie. "Basic conclusion on the above context, implicit and explicit determine which abolished customary justice-based emergency law is customary justice in the sense of inheemscherechtspraak, while authorities of customary justice carried out by the heads of the unity of indigenous communities where village justice continues. Whereas before, in the days of the Dutch East Indies, customary court is recognized in two forms: justice or justice indigenous peoples and village courts. This dimension then continued to be recognized in the days of the Japanese occupation where customary justice takes place, although Act No. 14 of 1942 (amended by Act No. 34 of 1942), has simplified the system of justice where judicial differences Gubernemen and justice for indigenous people have been eliminated. Sudikno Mertokusumo mention that in Sumatra, customary justice shall remain valid and maintained pursuant to Article1 of the law and Court Rules Judge contained in Otsu Tomi-Seirei-No. 40 dated December 1, 1943. 
Third, studied from a juridical perspective, theoretical, sociological, and philosophical implicit and explicit existence of customary courts must be recognized. The aspects and dimensions of the starting point to the provisions of Article 18B Paragraph (2), Article 28 paragraph (3), and Article 24 paragraph (3) Constitution of Republic of Indonesia, 1945, Decree No. IX/MPR/2001, Act No. 17 of 2007 and Decree of the President No. 7 of 2005. Conclusions basis of these provisions essentially regulated, recognized, and respected the existence of the unity of indigenous peoples and their traditional rights. Then, lack of respect for cultural identity, cultural diversity, and the rights of the nation as part of human rights are in tune with the times and civilizations. Next, recognize the existence of justice agencies as part of the judicial power set out in the legislation. In addition, the dimensions of the provisions examined from the perspective of juridical, political, and constitutional means the law recognizes traditional rights of indigenous society unity in customary law. Philosophical perspective, lack of respect, recognition and existence of human values and human rights by the state, and the right to carry out justice, which must then be translated into judicial power law. In the sociological perspective, indigenous justice as part of the traditional rights of indigenous and tribal people's unity in fact still lives in the community. Sociological fact, it is relatively not getting the recognition, and the existence of the traditional rights of indigenous and tribal people's unity should be followed up by the state laws and national legislation. Logical consequence of this dimension means the recognition of traditional rights of indigenous people in the Constitution of the Republic of Indonesia in 1945; the existence of customary judicial imperative is also recognized in law. In reality, it turns out until now that there has been no legislation that applies nationwide to provide recognition of the existence of customary justice.

Fourth, the policy level is that local legislation still recognized the existence of indigenous justice. At present, it is recognized customary justice in Constitution No. 21 in 2001 on Special Autonomy for Papua and Aceh Nanggroe Darussalam for the area as Constitution No. 11 in 2006 on Aceh Governance existence Indigenous Court still applied and is known as the Village Customary Court or Court of Peace. The provisions of Article 50 paragraph (1) states that "The judicial power in Papua fees implemented by the Courts in accordance with the legislation," the next paragraph (2) reads, "In addition to the judicial authorities referred to in paragraph(1), recognized the existence of customary law in the particular customary law communities." Then, in Article 9, paragraph (3) of the Special Province of Papua No. 20 of 2008 on the Papuan Customary Court stated that "the administration of court administered by judges customary law."

Fifth, however, national policy does not recognize the existence of indigenous justice and actual facts factual jurisprudence policies applied by the Supreme Court to admit the existence of customary justice remained. For example, as one example, the Supreme Court Decision No. 1644 dated May 15, 1991, K/Pid/1988 where the ratio decidendi ruling stated that if someone is violating customary law and the then head of Indigenous Leaders react customary (customary sanctions/indigenous medicine), then the question cannot be asked anymore (for the second time) as a defendant in the trial of the State Courts (District Court) with the same charges and customs unlawful imprisonment imposed under the provisions of the Criminal Code (Article 5 paragraph (3) sub b drt Act No. 1 of 1951) that in such circumstances, the transfer of the case file as well as the demands of Attorney in the District Court must be declared unacceptable. Conclusion basis of the jurisprudence of the Supreme Court determines that the Supreme Court as the High Courts in Indonesia continue to respect the decision of the Head of Indigenous (Indigenous leaders) who provide "customary sanctions/indigenous medicine" against violators of norms of customary law. General Courts cannot justify or prosecute offenders for the second time; these customs necessitate imprisonment (ex Article 5 paragraph (3) sub b darts of Law No. 1 of 1951, the articles of the Criminal Code). Therefore, it can be said that the logical consequence, if the traditional leader never gives "sanctions customary/indigenous medicine" against violators of customary law, the judicial magistrate judge states full authority under the provisions of Article 5, paragraph (3) sub b of Law No. 1 of darts 1951 articles of the Criminal Code.

Sixth, studied from the perspective of the future customary justice in reality is still around the level of the concept of the Draft Law (Draft) prepared by the Regional Representative Council (DPD) and the House of Representatives (DPR). Protection of Indigenous Peoples on the bill drafted by the Regional Representative Council in 2009 in Article 7 is set on Indigenous Institute, while the provisions of Article 8 are set on Indigenous Justice. The provisions of Article 8 state the following: (1) Courts are part of the indigenous customary institutions; (2) customary courts have jurisdiction to try all cases that occur are committed by members of indigenous peoples and indigenous territory concerned; (3) the decision of the customary court referred to in paragraph(2) shall be binding and final.; and (5) in the event, a case occurs in a region of an indigenous custom where one party is not a member of the indigenous peoples concerned, the settlement is done through the judiciary in accordance with the legislation in force. 
Then, the bill on the Recognition and Protection of Indigenous People who prepared the DPR in 2012 in Chapter III Paragraph 5 of the Right To Run Indigenous Law and Justice Article 18 paragraph (1) states that society has the right to hold the customary law of indigenous justice system in resolving disputes associated with customary rights and customary law and violation of paragraph, (2) states that further regulation of the right to exercise customary law and justice referred to in paragraph (1) is regulated by the government. The concept of the Bill on Protection of Indigenous Peoples and the DPD proposed Bill on the Recognition and Protection of the Rights of Customary Peoples filed by the House of Representatives will essentially remain a high honor existence to the enactment of customary law for the Indonesian people.

\subsection{Initiating the Concept of Customary Indonesian Judicial Ideal in the Future}

\subsubsection{Customary Law Is Independent Law}

The concept of an independent judiciary is not a customary necessity. Examined from the perspective of juridical, philosophical, sociological, and theoretical aspects and dimensions of the starting point to the provisions of Article 18B Paragraph (2), Article 28 paragraph (3), and Article 24 paragraph, and (3) the Constitution of the Republic of Indonesia, 1945, Decree No. IX/MPR/2001, Act No. 17 of 2007 and Presidential Decree No. 7 of 2005. Conclusions basis of these provisions essentially regulated, recognized, and respected the existence of the unity of indigenous people and their traditional rights. Then, lack of respect for cultural identity, cultural diversity, and the rights of the nation as part of human rights is in tune with the times and civilizations. Next, recognize the existence of justice agencies as part of judicial power set out in the legislation.

In addition, the dimensions of the provisions examined from the perspective of juridical, political constitutionally legal means recognizing the traditional rights of customary and tribal people's unity in casu customary law . Philosophical perspective, lack of respect, recognition, and existence of human values and human rights by the state, as well as in terms of implementing the right of justice, which must then be translated into Indonesian politics of judicial power law. In a sociological perspective, customary law as part of the traditional rights of indigenous and tribal people's unity in fact still lives in a society where it turns sociological facts relative to political recognition in the law of judicial power. In a theoretical perspective, lack of respect, recognition, and existence of the unity of the traditional rights of indigenous and tribal peoples should be followed up by the state legislation. The logical consequence of this dimension means the recognition of traditional rights of indigenous people in the Constitution of Republic of Indonesia in 1945, should the existence of indigenous justice imperatives are also recognized in law. However, in reality, it turns out that until now, no law applies nationally to recognize the existence of customary law.

From a historical perspective, customary law actually never acknowledged its existence. There are two forms customary law in the days of the Dutch East Indies. First is indigenous justice. Justice is carried out by the European justice and judges also from Indonesia, not on behalf of the King and Queen, not based on European legal system, but the system of customary law stipulated the resident with approval of the Director of Justice at Batavia. The existence of this court under the provisions of Article 74 of the RR/Article 130 IS decisive, "where the natives are not allowed to have their own justice, administered justice throughout Indonesia on behalf of the King. Where the population has left the judiciary alone, there is genuine justice. Second is the justice village. Justice is carried out by the judge or judges. Indigenous village is good for environmental justice Gubernemen, judicial indigenous/customary justice, and judicial self-government outside Java and Madura, the authority to hear matters little which is indigenous affairs and village affairs. The village has long been the true court that prevailed in the society in the rural life, and it acknowledged the new Dutch government since 1945, Article 3a RO with Stb 1935 No. 102.

During the Japanese occupation, customary law took place and continued to be recognized, although the Act No. 14 of 1942 (amended by Act No. 34 of 1942) has simplified the system of justice where judicial differences Gubernemen and justice for indigenous people has been eliminated. Sudikno Mertokusumo mention that in Sumatra, firm customary law shall remain valid and be maintained pursuant to Article 1 of the law and Court Rules Judge contained in Otsu Tomi-Seirei-No. 40 dated December 1, 1943.

In the next period, the era drt Act 1 of 1951, the existence of customary court began to be not recognized and thus removed. The provisions of Article 1 (2) 1 drt Act of 1951 states that "At the time gradually will be determined by the Minister of Justice was abolished...all customary courts except if the religious courts of justice according to law that life is a separate part of the Indigenous justice." Then, the article mentions an authentic explanation of the basis for consideration of the abolition of customary courts that do not qualify for the equipment as requested by the court and the Provisional Constitution of undesirable people. 
However, the abolition of customary law in the context of the above, not essentially eliminate the type of justice that is customary in other forms of village justice. Aspects and dimensions of the starting point as the provisions of Article 1 (3) 1drt Act of 1951, which asserted that "The provisions mentioned in subsection (1) is not the slightest power to reduce the rights had been given to the judges of the peace in villages referred to in article 3a Rechterlijke Organisatie." Basic conclusion on the above context, implicitly and explicitly determines which abolished customary law-based emergency law is customary justice in the sense inheemsche rechtspraak, whereas the customary judicial authority carried by the community unit heads of customary law is village justice continues. Emergency law is customary justice in the sense inheemsche rechtspraak, whereas the customary judicial authority carried by the community unit heads of customary law is village justice continues.

Later, the long journey through the judicial authority law (Act No. 19 of 1964, Act No. 14 of 1970, Act No. 35 of 1999, Act No. 4 of 2004, and Act No. 48 of 2009), does not recognize the existence of customary law. In the law courts determined as the only state judiciary in Indonesia, so the customary law clearly does not recognize its existence.

At present, it is recognized a customary law in Law No. 21 of 2001 on Special Autonomy for Papua and Aceh Nanggroe Darussalam for the area as Law No. 11 Year 2006 on Aceh Governance existence Customary Court still applied and is known as the Village Customary Court or Court of Peace. The provisions of Article 50 paragraph (1) states that "The judicial power in Papua fees implemented by the Courts in accordance with the laws and regulations", then paragraph (2) reads, "In addition to the judicial authorities referred to in paragraph (1), and recognized the existence of customary law in the particular customary law communities." Then, in Article 9, paragraph (3) of the Special Province of Papua No. 20 of 2008 on the Papuan Customary Court stated that, "the administration of justice administered by judges indigenous customary." Then, Article 51 of Law No. 21 of 2001 more mentions the following: (1) The customary courts is courts of peace in the customary law community, which has the authority to examine and adjudicate disputes customary law and criminal cases among the residents of indigenous communities concerned; (2) the Courts the customary of the customary law ordered by the indigenous peoples concerned; (3) the customary courts examine and adjudicate civil disputes and criminal cases custom referred to in paragraph (1) based on customary laws of indigenous communities concerned; (4) in the event that one of the parties to the dispute or the litigants objecting to the decision that has been taken by the customary court referred pad check paragraph; (3), the objecting party has the right to ask the court of first instance in the courts, the authority to examine and re-adjudicate disputes or matters in question; (5) the customary court is not authorized to impose a sentence of imprisonment or confinement; (6) customary court decision concerning a criminal offense that his case was not sought re-examination as referred to in paragraph (4), be final and binding judgment; (7) to release the criminal offender from criminal prosecution under the provisions of criminal law, necessary for the consent of the Chairman of the District Court held that obtained through the Chief State Prosecutor is concerned with a criminal incident as described in paragraph (3); and (8) in the event that a request for consent to be implemented in the custom court decision referred to in paragraph (7).

The essence of the above dimensions fundamental customary law recognized that the scope is local, but in the national side, it is relatively less customary court recognition. In addition, the dimensions of saying that there is no connection between the politics of law in the legislation (Article 18 BParagraph (2), Article 28 paragraph (3) and Article 24 paragraph (3) Constitution of Republic of Indonesia 1945), which should be further elaborated by regulations legislation, but the reality has not yet been translated further by the state.

Examined from the perspective of the future customary law in reality is still around the level of the concept of the Draft Law (Draft) prepared by the Regional Representative Council (DPD) and the House of Representatives (DPR). Protection of living on the bill drafted by the DPD in 2009 in Article7is set on Indigenous Institute, whereas the provisions of Article 8 are set on Customary Court.

In the detailed provisions of Article 7 reads: (1) customary institutions have the authority to regulate, administer, and prosecute members of indigenous peoples; (2) in performing its duties customs agency has the authority to represent members of indigenous communities both collectively and as individuals in any legal actions and legal events that occurred; (3) procedures, structures, and working procedures of traditional institutions in accordance with customary structures prevailing in the respective indigenous peoples. The provision of Article 8 reads:

(1) the customary courts are part of the traditional institutions; (2) customary courts have jurisdiction to try all cases that occur are committed by members of indigenous peoples and indigenous territory concerned; (3) the decision of the customary court referred to in paragraph (2) shall be binding and final; and (4) in the event a case occurs in a region of an indigenous custom where one party is not a member of the indigenous peoples concerned, the settlement is done through the judiciary in accordance with the legislation in force. 
Then, the bill on the Recognition and Protection of Indigenous People who prepared the DPR in 2012 in Chapter III Paragraph 5 of the Right To Run Customary Law and Justice Article 18 states that: (1) the public has the right to hold the customary law of custom law system in resolving disputes relating to customary rights and a violation of customary law and (2) further regulations regarding the right to exercise justice and customary law as referred in paragraph (1) is regulated by the government.

The concept of the Bill on Protection of Indigenous Peoples and the DPD proposed Bill on the Recognition and Protection of the Rights of Indigenous Peoples filed by the House of Representatives will essentially remain high honor existence to the enactment of indigenous justice for the Indonesian people. If the described context of indigenous justice initiated an ideal model is independent of this it can be seen in the Figure1 below form.

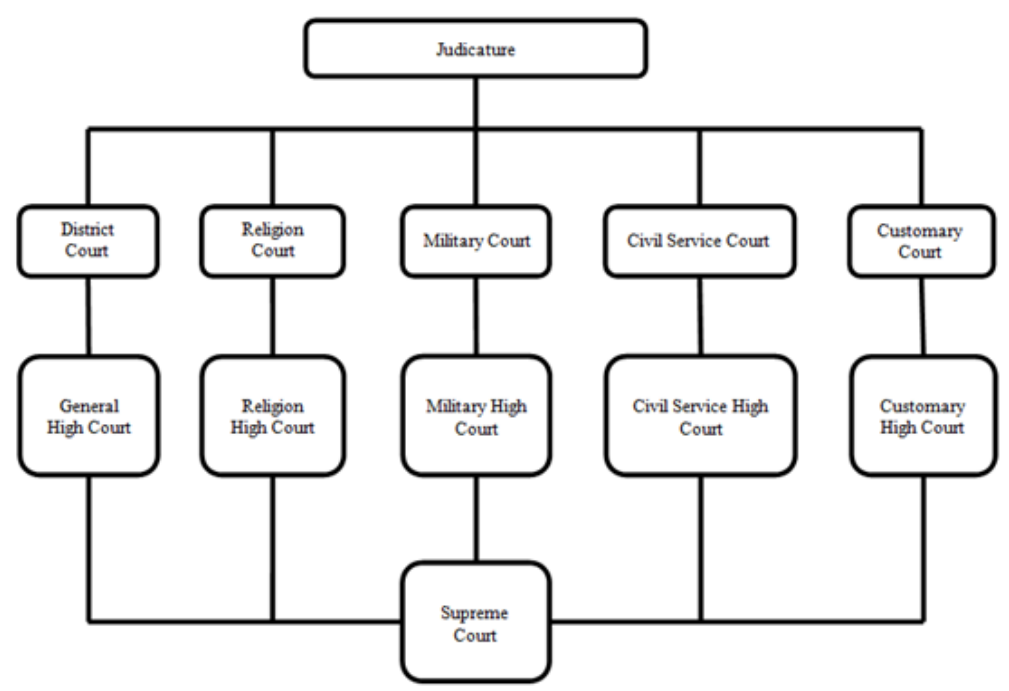

Figure 1. The concept of independent custom court

In essence, the establishment of Customary Courts is independent of this nature who wants more seats the position of customary law, traditional institutions and customary laws functionaries sociological, philosophical, theoretical, and normative parallel (same level) with the national legal system. Precisely, indigenous customary law in parallel with the formal legal caqu into the institution of judicial power. In practice, local knowledge of customary law in a criminal case is mostly done outside the criminal justice system of customary courts resolved. In an international perspective, this dimension is also in line with the provisions of Article 5 of the Declaration on the Rights of Indigenous Peoples, which was passed on September 7, 2007 to determine that, " Indigenous peoples have the right to maintain and strengthen political institutions, legal, economic, social and cultural, while retaining their right to participate fully if they choose, in the political, economic, social, and cultural rights of the State". Next, in Section 34 is also determined, " indigenous peoples have the right to promote, develop, and maintain institutional structures and customs, spirituality and traditions, procedures, practices they are different, and in case if there are, their judicial systems or customs, in accordance with the standard - international human rights standards.".

However, although such an ideal concept formation is independent Indigenous Justice does not mean do not have weaknesses, constraints and implications and raises questions that are correlated with the implementation of the legal basis and authority of Indigenous Justice, the principle or principles of Customary Courts, Customary Court functionaries, process or mechanism Justice indigenous and indigenous Justice finally for the administration. Examined from the perspective of normative, theoretical emperies and the existence of customary law institutions raises questions and some doubts. Thus elaborated further dimension as reflected in the views SiclairDinnen following: (a) the fact that most of the indigenous justice held by those who are old, in which a framework of thinking of them often do not see the development of conditions in the community, especially the younger generation. This affects the decision made as to discriminate against women and children (especially in patrilineal societies); (b) the notion that in any customary judicial culture of nepotism and corruption-prone; (c) the strength of the force of customary judicial decisions often questionable; (d) principles and objectives of the judicial punishment of opposing the existing formal system so that the impact of the decisions made was very 
different (in this case I do not see what the impact is a positive or negative impact); and (e) that the customary justice institutions will only be effective and binding in traditional societies homogeny but would be very different if applied within the scope of urban area.

Regardless, of the existence of weaknesses, constraints, questions and excess dimension in the context of the above, the selection or creation of Customary Courts are essentially independent of a choice of how the political dynamics of the existence of the law fore Justice Indigenous ways of looking at one side with the formal law on the other.

\subsubsection{Customary Courts in the General Court}

In this context, indigenous justice included in the general court room. Nature of customary justice here is "quasi" or "collaborative approach". That is, in the general court, there will be two (2) rooms, the District Court room and Customary Court Room. Special to the Customary Court of General Jurisdiction of this room, the judge who will hear the case is a mixture of indigenous Justice with Judge Ad Hoc career. However, the Ad Hoc difference here is not permanent as it is known as today, but temporary. Strictly speaking, the Ad Hoc Judge will hear all the existing custom cases and when it has finished with the customary court of the status of the Ad Hoc back to normal.

Customary justice are "quasi" or "collaborative approach" perceived effective, efficient and in accordance with the factual conditions of the times. In this model, then the remedies, there are two possible options that can be done. First, do an appeal to the High Court as the Court of Appeal of Indigenous Peoples. In Customary Court of Appeal also tried by Judge mixture career with the Ad Hoc. Similarly cassation to the Supreme Court, so the logical consequences of the court of appeal should exist also Cassation Indigenous Room . Other possibilities can also be judged on appeal by the Supreme Court in Criminal Room/Room Special Criminal and Civil/Special Civil cases depending on the type of entry. The logical consequence of this dimension; it is next necessary addition of knowledge, mastery of customary law, and the experience of the judge 's career at Court Room Traditional , Customary Court of Appeal and Supreme Court Justice in Criminal Room / Room Special Criminal and Civil / Civil Special .

If the dimensions are chosen so that the form of Customary Courts in General Court can be seen as Figure 2 below.

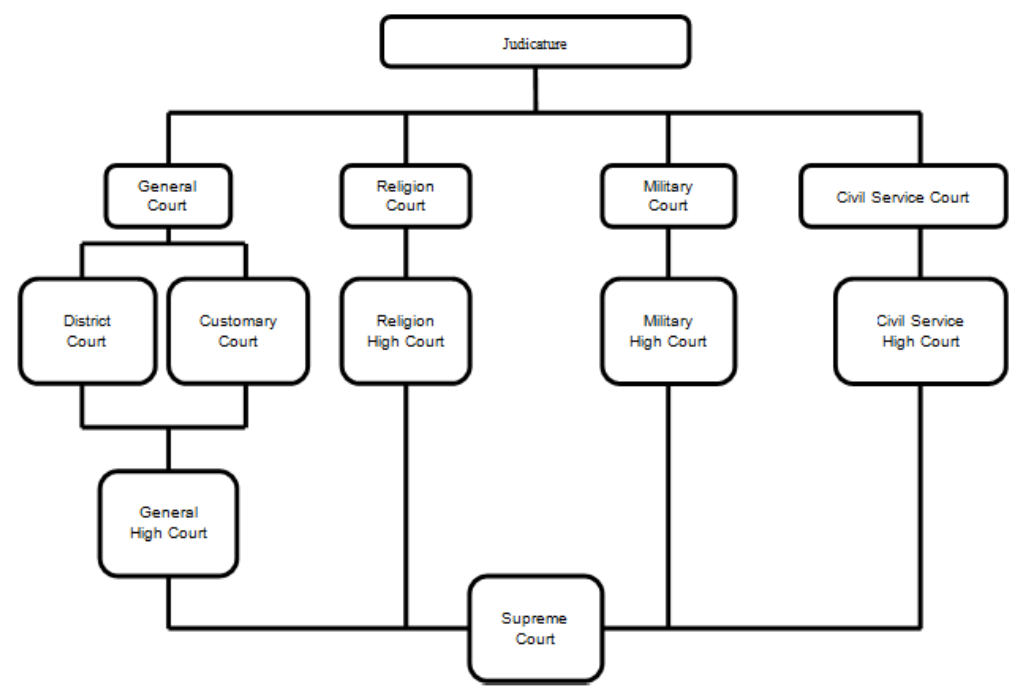

Figure 2. Customary courts in general court

Second, to make it more efficient, streamlined, effective, and with the perspective that the specific dimensions of indigenous cases; it can also open the possibility that the case should not be custom made an appeal, so it is not necessary to Customary Court of Appeal. Against indigenous cases both criminal cases and civil cases indigenous customs that have been decided by the Customary Court of General Jurisdiction In the room, his legal efforts can only be made legal efforts to appeal directly to the Supreme Court.

If the model is to be chosen in the form of Customary Court Room General Court can be seen as Figure 3 below. 


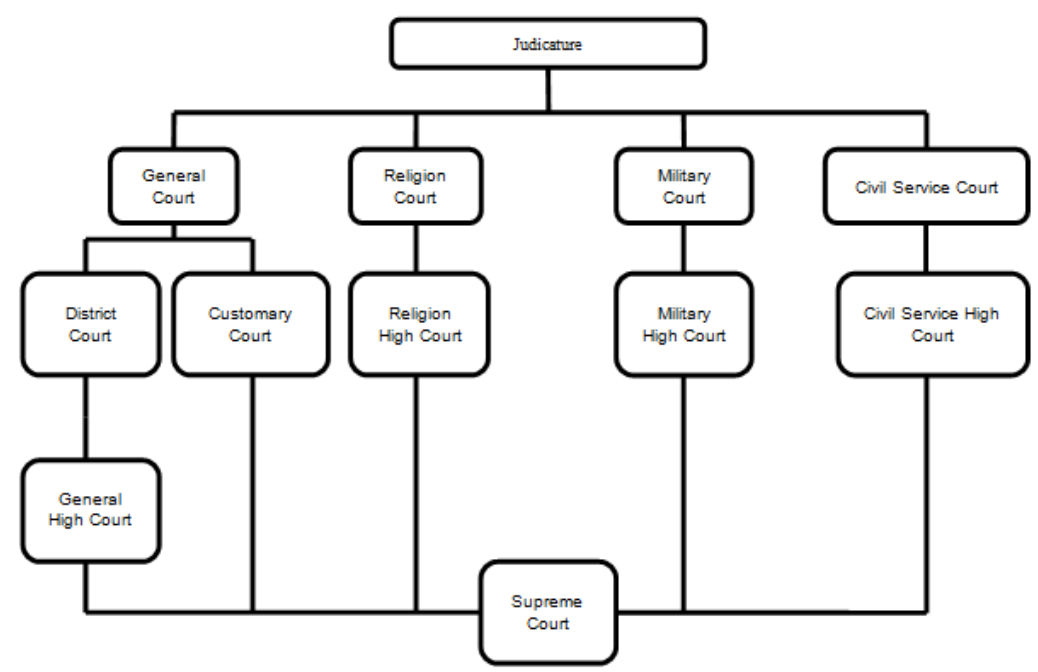

Figure 3. Customary court in general court without indigenous high court

In essence, traditional justice model selection in general court room as Charts 2 and 3 , has advantages and disadvantages. In Figure 2, it is possible to do with an appeal to the High Court Custom and then glance over to accommodate the dimensions of human rights because of criminals or the plaintiff / defendant in civil case custom, still accommodated rights in all forms of justice. However, its shortcomings would means there to the facilities, infrastructure and financial dimensions of the state to form a Customary Court of Appeal. However, if the selected Chart 3 then briefly the limitations on legal remedies that can be done by the perpetrator or the plaintiff / defendant in a civil case custom, so will the dimension restrictions on human rights. Its advantages because the state can finance is not necessary facilities, infrastructure and human resources to build the High Court Peoples. In addition, the efforts of law directly to the Supreme Court, then put a custom case are a special case that interventions should be prioritized, specific, serious, and exclusive.

In addition to the above dimensions, the implications of Customary Courts In General Court, will result in the need for more in-depth thoughts on the types of cases that can be dealt with just about anything and is a jurisdiction of the District Court and Customary Court. In this context, it is necessary to have a deeper thought is needed so that the problem does not arise and adding new trial when the model has been run.

\subsubsection{Passing the General Court Case with Accommodating Indigenous Traditional Values}

In this model, the General Court Justice for Indigenous Case With Accommodating Indigenous Values is a general model that has been implemented as it is today in Indonesia. In addition to the cases that have been described and discussed above, the model is also done in some areas. For example, for most areas of West Sumatra is condensed in the field of civil law where the law is applied customary law regions of West Sumatra and Bali in particular for criminal law section.

From this dimension, it can be said that there is an intermingling of the provisions of national law with customary law. Precisely, the national procedural law to accommodate the values of customary law when the judge ruled. Aspects and dimensions is seen for example in the Decision No.21/Pid.B/2009/Pn. And Decision No. Srln. 22/Pid.B/2009/Pn. Srln as follows: Sorolangun Jambi District Court sentenced to Celitai and Eye Mountain Hero Member for three months and twenty days for violating Article 351 paragraph (1) of the Criminal Code and Article 170 of the Criminal Code. A cursory look nothing special in the decision, but it caused the existence of customary law in the midst of our positive law. It is suspected that the decision was linked to the completion of customary where his decision, the warring parties fined the customary form of fabric which is considered as a replacement rokhani loss. With one person dead reckoning counted 500 fabrics. Hero Member Group Celitai paid 1000 fabrics to Madjid, whereas the 500 cloth to Madjid pay Celitai group.

The dimensions of the decision are interesting because the case settled prior custom and ends through a court decision. In essence, the judge's decision was considered customary settlement that formed the basis for the convict. Similarly, in a civil case in which the judge ruled on the point of departure to the dimension of the local customary law. For example District Court No. Lubuk cone. 17/PDT/G/2009/PN.LB.BS dated June 21, 2010 the principal injunction as follows: (1) Declare Plaintiff ARPENDI Rangkayo NOBLE is Mother of Hereditary 
Chief of the Tribe DT. SATI Bagindo Pasukuan Malay in Jorong Aurand Jorong Jalikur, Koto Kenagarian Tangah, Tilatang Kamang, Agam derived from the off spring that upik grandmother (deceased) Malay; (2) Declare Plaintiff ARPENDI Rangkayo RUNUN NOBLE with DT. Bagindo SATI, mamad DT. Bagindo SATI and Mahyudin DT. Bagindo SATI is sekaum, sepenghulu, serandji, seharta sepusaka, sehina semalu, segolok segadai dan sesasok sejurami; (3) Stating appointment Albar, SE., As The penghoeloe The DT. BAGINDO SATI Forces Malay in Jorong Aur and Jorong Jalikur, Koto Kenagarian Tangah, Tilatang Kamang Vilage, Agam derived from a common ancestor that upik grandmother (deceased) The Malays are legally valid; (4) To declare the entire Land of Object Case The Plaintiff was rightfully belongs.

Criminal Code Draft of 2012 to accommodate clear about the values that live in a society of law (customary law) and side by side with the procedural provisions of national law. The provisions of Article 2 of the Criminal Code Bill determines that (1) The provisions referred to in Articlelparagraph (1) Without prejudice to the laws that live in a society that determines that a person should not be convicted even though such actions stipulated in laws and regulations; (2) The enactment of laws that live in the community as referred to in paragraph (1) to the extent consistent with the values contained in Pancasila, human rights, and the general principles of law recognized by the community of nations.

The Elucidation of Article 2 Paragraph (1) :Law is the law of life means living in community life of Indonesian law. The legal form of the legal community who live in Indonesia, such as in certain parts of Indonesia there are unwritten laws that live in the community and serves as the law in the area. Such things are also in the field of criminal law that is usually referred to by the customary criminal offenses. To provide a solid legal basis for the enactment of customary criminal law, then it gets the settings explicitly in the Code of Criminal. This paragraph is an exception to the principle that penal provisions stipulated in the legislation. Admittedly the customary criminal offense to better satisfy the justice that lives in a particular society. Paragraph (2) This paragraph contains guidelines or criteria or the guidelines in determining the source of the material law (law who live in the community) that can be used as a source of law (legality source material). The guidelines in this paragraph oriented values contained in Pancasila as a source of national law, human rights, the principles of the common law recognized by the community of nations.

\section{Conclusion}

Essentially, Indigenous Justice in Indonesia dimensions between "no" and "no". These dimensions can be seen from the principle of legality, the normative perspective drt Act 1 of 1951, the policy of block legislation and jurisprudence of the Supreme Court. In judicial practice of the State, many decision has been handed down by the judiciary against criminal cases and civil cases custom.

For the foreseeable future, in the Customary Court initiated an ideal concept oriented to three (3) models Customary Courts. First, Indigenous Justice is independent. Second, Justice Custom In General Court. Third, the General Court Justice for Indigenous Case with Accommodating Indigenous Values.

The selection of the three alternative models in Indigenous Justice initiated the concept of the ideal future is a choice of how the political dynamics of the existence of the law for Justice Indigenous ways of looking at one side with the formal law on the other. Strictly speaking, if the Customary Court will be chosen level with Formal Law (National Law) that is independent; is part of the Formal Law (National Law) entered the room so that the General Court, or custom values so as to be accommodated in the National Law National Law higher than Customary Law as dynamic as it is today.

\section{References}

Arief, B. N. (1994). Beberapa Aspek Pengembangan Ilmu Hukum Pidana (Menyongsong Generasi Baru Hukum Pidana Indonesia). Semarang: Law Faculty of Dipponegoro University.

Arief, B. N. (2010). Kebijakan Legislatif Dalam Penanggulangan Kejahatan Dengan Pidana Penjara. Yogyakarta: Genta Publishing.

Bassiouni, M. C. (1987). Substantive Criminal Law. Illionis: Charles C. Thomas Publisher.

Dinnen, S. (2003, November). Interfaces Between Formal and Informal Justice System To Strengthen Access to Justice By Disadvantaged System. Paper presented at UNDP Asia-Pasific Rights and Justice Initiative, Ahungala Sri Langka.

Indonesia Supreme Court. (1991). Penemuan Masalah Hukum dan Pemecahan Masalah Hukum Reader III Jilid I. Jakarta: Indonesia Supreme Court Publishing.

Mertokusumo, S. (2011). Sejarah Peradilan dan Perundang-undangannya di Indonesia Sejak 1942 dan Apakah 
Kemanfaatannya Bagi Kita Bangsa Indonesia. Yogyakarta: Atma Jaya University Publishing.

Mulyadi, L. (1987). Delik Adat "Lokika Sanggraha" Di Bali, Majalah Varia Peradilan. Jakarta: IKAHI Publishing.

Mulyadi, L. (2010). Pengkajian Asas, Teori, Norma, Praktik dan Prosedurnya, untuk wilayah Pengadilan Tinggi Banda Aceh, Medan, Denpasar, Mataram dan Banjarmasin, Juni-Juli 2010, Jakarta.

Salman, H. R. O. (2002). Rekonseptualisasi Hukum Adat Kontemporer. Bandung: Alumni.

Sembayang, M. (2009). Hukum Adat Rimba dan Hukum Positif. Jakarta: Prakarsa Rakyat.

Wignjodipuro, S. (1979). Pengantar dan Azas-Azas Hukum Adat. Bandung, Alumni.

\section{Copyrights}

Copyright for this article is retained by the author(s), with first publication rights granted to the journal.

This is an open-access article distributed under the terms and conditions of the Creative Commons Attribution license (http://creativecommons.org/licenses/by/3.0/). 